\title{
Technological quality and yield of sugarcane grown under nitrogen doses via subsurface drip fertigation
}

\author{
Andressa F. L. Rhein ${ }^{1}$, Renata P. Pincelli², Marcel T. Arantes ${ }^{3}$, \\ William J. Dellabiglia ${ }^{4}$, Oriel T. Kölln ${ }^{5}$ \& Marcelo de A. Silva ${ }^{6}$ \\ ${ }^{1}$ Prefeitura do Município de São Paulo/Secretaria do Verde e do Meio Ambiente. São Paulo, SP. E-mail: andressarhein@prefeitura.sp.gov.br \\ ${ }^{2}$ University of Minnesota/Department of Horticultural Science. Minnesota, United States. E-mail: renats_9@yahoo.com.br \\ ${ }^{3}$ Zilor - Usina Açucareira Quatá S/A. Quatá, SP. E-mail: arantes_mt@zilor.com.br \\ ${ }^{4}$ Universidade Estadual Paulista "Júlio de Mesquita Filho"/Faculdade de Ciências Agronômicas/Departamento de Engenharia Rural. Botucatu, SP. E-mail: \\ wjdellabiglia@gmail.com \\ ${ }^{5}$ Laboratório Nacional de Ciência e Tecnologia do Bioetanol. Campinas, SP. E-mail: oriel.kolln@bioetanol.org.br \\ ${ }^{6}$ Universidade Estadual Paulista "Júlio de Mesquita Filho"/Faculdade de Ciências Agronômicas/Departamento de Produção e Melhoramento Vegetal. \\ Botucatu, SP. marcelosilva@fca.unesp.br (Corresponding author)
}

\section{Key words:}

Saccharum spp.

nitrogen fertilization

full irrigation

pol\% cane

yield

\begin{abstract}
A B S T R A C T
This study characterized the technological quality and yield of sugarcane cv. SP80-3280 under nitrogen doses via subsurface drip fertigation. Five treatments were established using $\mathrm{N}$-fertilizer in the form of urea $\left(0,50,100,150\right.$ and $\left.200 \mathrm{~kg} \mathrm{~N} \mathrm{ha}^{-1}\right)$, with four replicates, applied via subsurface drip fertigation. The technological quality (fiber\% cane; Brix\% juice; pol\% juice, pol\% cane; juice purity and total recoverable sugar - TRS), as well as yield of stalks and sugar were determined 381 days after the third harvest. The technological variables Brix \%, pol\% juice, purity\% and TRS of sugarcane, cultivar SP80-3280, were altered by the application of nitrogen doses via subsurface drip fertigation, with significant reductions at the dose of $200 \mathrm{~kg} \mathrm{~N} \mathrm{ha}^{-1}$. Stalk and sugar yields increased linearly with the increment in nitrogen doses applied through subsurface drip fertigation.
\end{abstract}

\section{Palavras-chave: Saccharum spp. adubação nitrogenada irrigação plena pol\% cana produção}

\section{Qualidade tecnológica e produtividade da cana-de-açúcar sob doses de nitrogênio via fertirrigação subsuperficial por gotejamento}

\footnotetext{
R E S U M O

Neste trabalho foram avaliadas a qualidade tecnológica e a produtividade da cana-de-açúcar cv. SP80-3280 sob doses de nitrogênio via fertirrigação subsuperficial por gotejamento. O ensaio foi instalado e conduzido em campo em blocos casualizados com cinco tratamentos e quatro repetições. Os tratamentos consistiram de doses de nitrogênio $(0,50,100,150$ e 200 $\mathrm{kg}$ de $\mathrm{N} \mathrm{ha}^{-1}$ ) na forma de ureia aplicadas via fertirrigação por gotejamento subsuperficial. Aos 381 dias após o terceiro corte foram determinadas a qualidade tecnológica (fibra\% cana; Brix\% caldo; pol\% caldo; pol\% cana; pureza do caldo e açúcar total recuperável) e a produtividade de colmos e de açúcar. As variáveis tecnológicas Brix, pol\% caldo, pureza\% e açúcar total recuperável (ATR) da cultivar SP80-3280 de cana-de-açúcar foram alteradas mediante a aplicação das doses de nitrogênio via fertirrigação subsuperficial por gotejamento com reduções significativas na dose de $200 \mathrm{~kg} \mathrm{~N} \mathrm{ha}^{-1}$. As produtividades de colmos e de açúcar aumentaram linearmente com o aumento de doses de nitrogênio via fertirrigação por gotejamento subsuperficial.
} 


\section{INTRODUCTION}

Sugarcane (Saccharum spp.) originated in southeast Asia, in the central region of New Guinea and Indonesia, and is an allogamous plant, with semi-perennial cycle and great rusticity. Brazil is the largest sugarcane producer and the first in the world in the production of sugar and alcohol, besides being the precursor of the use of biofuel as an energetic alternative (Mozambani et al., 2006).

Sugarcane cultivation is still in expansion in Brazil, especially in the states of the Midwest and Southeast regions and in the state of Paraná, in the south of the country (CONAB, 2014). It is cultivated in different types of soil, under the influence of various abiotic factors that are peculiar to each region, performing different levels of production (Silva et al., 2008).

Among the various abiotic factors, water deficiency must be highlighted due to the harmful effects caused on plant development, primarily through the reduction of cell expansion. The problems caused by the decrease in soil water availability are common in sugarcane fields, since they are not limited to only arid and semiarid regions in the world. In regions considered as climatically humid, irregular rainfall distribution can, in some periods, limit plant growth (Silva et al., 2014).

Although this crop is adapted to conditions of high luminosity intensity, high temperatures and relative water scarcity, water deficiency during the stages of growth and development can lead to expressive reductions in stalk and sugar yield (Dantas Neto et al., 2006). Thus, sugarcane producers depend greatly on irrigation to achieve production goals. However, this technique only has no applicability and needs to be combined with other agricultural management practices (Dalri et al., 2008), such as nitrogen fertilization, which is one of the main determinant abiotic factors for sugarcane production, especially with respect to the longevity of the ratoons (Muchow et al., 1996). Therefore, inadequate management of nitrogen fertilization in sugarcane fields may lead to reduction in crop yield and longevity, thus decreasing the number of harvests or cuts between the renovations (Vale et al., 2013).

Nitrogen is the nutrient most frequently applied through irrigation water, because, compared with other nutrients, such as phosphorus, potassium, calcium and magnesium, it has high mobility in the soil. However, it also has great potential of losses, especially through nitrate leaching (Roberts, 2008). Fertigation allows more movement of the nutrient in subsurface and laterally, which is considerably important in perennial and semi-perennial crops like sugarcane, due to the difficulty in incorporating fertilizers applied as top-dressing, without damaging the root system (Quintana et al., 2012).

The understanding on qualitative and quantitative attributes related to the supply of water and nitrogen will significantly contribute to recommending the best management for obtaining higher yields and agricultural productivity. Thus, considering the hypothesis that $\mathrm{N}$ doses do or do not promote alterations in the technological properties and yield of sugarcane, this study aimed to characterize sugarcane technological quality and the yield of stalks and sugar, as a function of nitrogen doses applied through subsurface drip fertigation.

\section{Material AND Methods}

The experiment was installed in September 2006, using the twelve-month sugarcane planting system, in an area close to the city of Jaú-SP, Brazil (22 $17^{\prime} \mathrm{S} ; 48^{\circ} 34^{\prime} \mathrm{W} ; 580 \mathrm{~m}$ ). The predominant climate in the region is Aw (Köppen), rainy tropical with dry winter and annual means of $22.7{ }^{\circ} \mathrm{C}$ of temperature and $1,344 \mathrm{~mm}$ of rainfall. The study was conducted from September 2009 to October 2010, after the $3^{\text {rd }}$ cut of the sugarcane cultivar SP80-3280, planted in soil classified as eutrophic Argisol (EMBRAPA, 2006). From 2006 to 2008, cycles of plant cane and ratoon, the experimental area was used for the development of the research published by Gava et al. (2011).

The experimental plots consisted of five paired-rows $(0.40$ $\mathrm{x} 1.40 \mathrm{~m}$ ), called "W" or "pineapple" planting, with length of 8 $\mathrm{m}$. The tubes of the irrigation system (DRIPNET PC $22135 \mathrm{FL}$, Adana, Turkey) were installed at a depth of $20 \mathrm{~cm}$ from the soil surface, between the double row of sugarcane, and had drippers every $0.5 \mathrm{~m}$ and flow rate of $1.0 \mathrm{~L} \mathrm{~h}^{-1}$, which were responsible for the application of doses of $\mathrm{N}$-fertilizer (urea) twice a week.

Nitrogen fertilization was performed along the seven development stages of the plants and interrupted four months before harvest, in the stage corresponding to maturation. In addition, $150 \mathrm{~kg} \mathrm{ha}^{-1}$ of $\mathrm{K}_{2} \mathrm{O}$ were applied in the experimental units, as $\mathrm{KCl}$, distributed along the cycle through fertigation, whose application was interrupted three months before harvest (Figure 1).

Soil water condition was monitored using tensiometers and the irrigation frequency was calculated considering an available water capacity in the soil (AWC) of $70 \mathrm{~mm}$, precipitation (P), atmospheric demand and sugarcane evapotranspiration (ETc). The total rainfall recorded during the experimental period was $1,435 \mathrm{~mm}$; the amount of water applied through the irrigation system was $390 \mathrm{~mm}$, distributed along the sugarcane development, in order to supply $100 \%$ of crop evapotranspiration, according to the method of PenmanMonteith (Howell \& Evett, 2004), whose accumulation was $1,320 \mathrm{~mm}$ (accumulated ETc). The water balance was estimated for every ten days and the water deficiency (DEF) showed a value of only $28 \mathrm{~mm}$ (Figure 2). The maximum and minimum

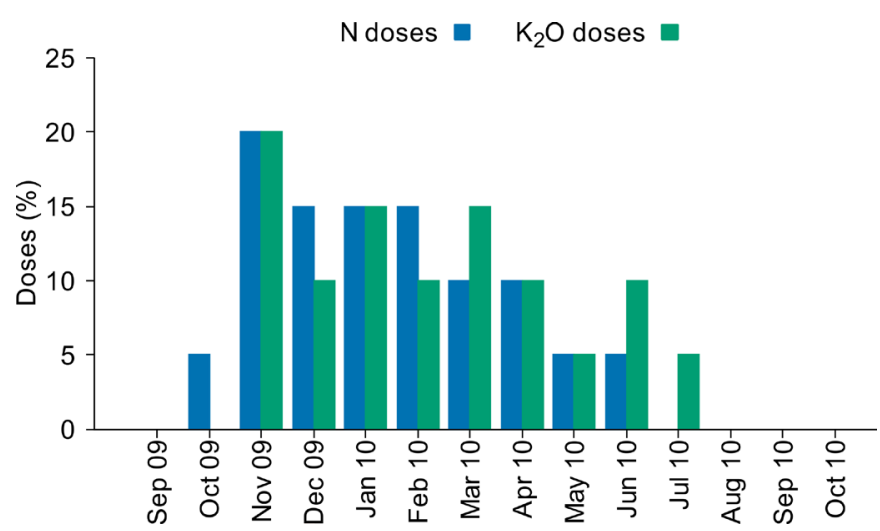

Figure 1. Percent distribution of doses of $\mathrm{N}$ and $\mathrm{K}_{2} \mathrm{O}$ applied through fertigation during the development of the experiment with ratoon cane 


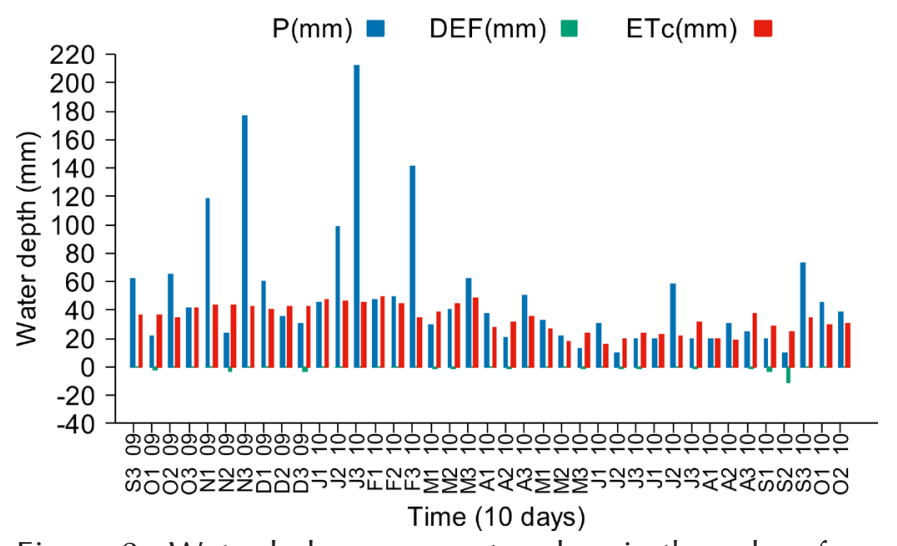

Figure 2. Water balance every ten days in the subsurface drip irrigation management from September 2009 to October 2010

temperatures observed during the development cycle of the crop were 29.2 and $16.4^{\circ} \mathrm{C}$, respectively.

For the treatments, five doses of $\mathrm{N}$-fertilizer $(0,50,100$, 150 and $\left.200 \mathrm{~kg} \mathrm{~N} \mathrm{ha}^{-1}\right)$, as urea $(45 \% \mathrm{~N})$, were established in a randomized block design, with four replicates, and their effects were evaluated at 381 days after the third cut (DAC). The following variables were analyzed: technological quality in 10 industrial stalks of sugarcane, taken randomly in the plots (industrial fiber content - fiber\% cane - F; soluble solids content - Brix\% juice - BRIX; apparent sucrose percentage pol\% juice - POL; sucrose contents in the cane - pol\% cane - PCC; apparent juice purity - PUR; total recoverable sugar - TRS) and yields of stalk (TStH) and sugar (TSgH)

Stalk yield ( $\mathrm{t}$ stalk ha ${ }^{-1}$, TStH) was determined by weighing the stalks, which were manually harvested in each plot, using a load-cell scale. Then, TStH was estimated considering the planting of 5,556 linear meters in 1 ha. Sugar yield (t sugar $\mathrm{ha}^{-1}, \mathrm{TSgH}$ ) was obtained through the product of TStH and the corresponding value of total recoverable sugar $\left(\mathrm{kg} \mathrm{t}^{-1}, \mathrm{TRS}\right)$ of each plot, divided by 1000 .

The data were subjected to analysis of variance by F test, followed by Tukey test $(\mathrm{p}<0.05)$ for the comparison of means. Polynomial regression was used for the follow-up analysis of the degrees of freedom of quantitative factors, nitrogen doses applied through subsurface drip fertigation.

\section{Results AND Discussion}

No effect of $\mathrm{N}$ doses applied through subsurface drip fertigation was observed on the variables industrial fiber content (F) and pol\% cane (PCC) (Table 1), as well as for the follow-up analysis of the degrees of freedom of these factors. F means ranged from 15.75 to $16.79 \%$ for the doses of 200 and $0 \mathrm{~kg} \mathrm{~N} \mathrm{ha}{ }^{-1}$ and PCC means from 15.7 to $17.53 \%$ for the doses of 200 and $100 \mathrm{~kg} \mathrm{~N} \mathrm{ha}^{-1}$ (Table 2), respectively.

This is probably due to the full irrigation; in these conditions, there is no restriction to internode and stalk length, whose cell walls have normal development and, therefore, the fiber content is conditioned by the characteristics of the cultivar.

Dalri \& Cruz (2008) obtained similar results in sugarcane cv. RB72454 fertigated by drip irrigation, with installments of $\mathrm{N}$ doses ranging from 60 to $180 \mathrm{~kg} \mathrm{ha}^{-1}$. These authors observed that the industrial fiber percent did not show significant alterations, remaining between 9.51 and 9.90 in the first ratoon and 10.39 and 10.83 in the second ratoon.

$\mathrm{N}$ fertigation affected the content of soluble solids (BRIX) and the apparent percentage of sucrose in the juice (POL) of sugarcane plants (Table 1 ), causing significant reduction in BRIX and POL from the dose of $100 \mathrm{~kg} \mathrm{~N} \mathrm{ha}^{-1}$ to $200 \mathrm{~kg}$ $\mathrm{N} \mathrm{ha}^{-1}$ (Table 2). This result is probably due to the fact that the $\mathrm{N}$, in doses higher than $150 \mathrm{~kg} \mathrm{ha}^{-1}$, associated with full drip irrigation, was absorbed in amounts greater than those required by the crop, thus characterizing luxury consumption (Muchow et al., 1996). Other studies have also pointed out the reduction in sugarcane BRIX and POL due to the effects of $\mathrm{N}$ doses higher than $120 \mathrm{~kg} \mathrm{ha}^{-1}$ (Franco et al., 2008; Megda et al., 2012).

The quality of sugarcane as industrial raw material can be defined as the succession of characteristics that are intrinsic to the plant, altered by agricultural and industrial management, which define the potential for the production of sugar and

Table 2. Means of the technological variables fiber $\%$ cane (F), Brix \% juice (BRIX), pol\% juice (POL), pol\% cane (PCC), apparent juice purity (PUR) and total recoverable sugar (TRS) of sugarcane CV. SP80-3280, obtained for nitrogen doses $\left(0,50,100,150\right.$ and $\left.200 \mathrm{~kg} \mathrm{ha}^{-1}\right)$ applied through subsurface drip fertigation

\begin{tabular}{|c|c|c|c|c|c|c|}
\hline \multirow{3}{*}{$\underset{\left(\mathrm{kg} \mathrm{ha}^{-1}\right)}{\mathrm{N}}$} & \multicolumn{6}{|c|}{ Technological variables $^{1}$} \\
\hline & $\mathbf{F}$ & BRIX & POL & PCC & PUR & TRS \\
\hline & \multicolumn{6}{|c|}{$(\%)$} \\
\hline 0 & 16.79 & $24.28 \mathrm{a}$ & $21.91 \mathrm{a}$ & 17.05 & $90.27 a b$ & $166.22 \mathrm{ab}$ \\
\hline 50 & 15.80 & $23.66 a b$ & $21.23 a b$ & 16.05 & $89.71 \mathrm{ab}$ & $164.15 a b$ \\
\hline 100 & 16.27 & $24.32 \mathrm{a}$ & $22.33 \mathrm{a}$ & 17.53 & $91.81 \mathrm{a}$ & $170.51 \mathrm{a}$ \\
\hline 150 & 16.04 & $23.60 a b$ & $21.38 \mathrm{ab}$ & 16.86 & $90.50 \mathrm{ab}$ & $164.41 \mathrm{ab}$ \\
\hline 200 & 15.75 & $22.62 \mathrm{~b}$ & $19.81 \mathrm{~b}$ & 15.70 & 87.53 b & $154.15 b$ \\
\hline LSD & 1.35 & 1.59 & 3.06 & 2.34 & 3.06 & 15.42 \\
\hline
\end{tabular}

LSD-least significant difference; ${ }^{1}$ Means followed by the same letter in the columns (treatments) do not differ by Tukey test $(p<0.05)$

Table 1. Mean squares of the analysis of variance for the technological variables fiber\% cane (F), Brix\% juice (BRIX); pol\% juice (POL); pol\% cane (PCC); apparent juice purity (PUR) and total recoverable sugar (TRS) of sugarcane cV. SP80-3280, obtained for nitrogen doses (0, 50, 100, 150 and $\left.200 \mathrm{~kg} \mathrm{ha}^{-1}\right)$ applied through subsurface drip fertigation at 381 days after the third cut (DAC)

\begin{tabular}{|c|c|c|c|c|c|c|c|}
\hline \multirow{2}{*}{$\begin{array}{c}\text { Source } \\
\text { of variation }\end{array}$} & \multirow{2}{*}{ DF } & \multicolumn{6}{|c|}{ Mean squares } \\
\hline & & $F$ & BRIX & POL & PCC & PUR & TRS \\
\hline $\mathrm{N}$ doses & 4 & $718 \times 10^{9 \mathrm{~ns}}$ & $188 \times 10^{10 *}$ & $365 \times 10^{10 *}$ & $224 \times 10^{10 n s}$ & $961 \times 10^{10 *}$ & $144 \times 10^{12 *}$ \\
\hline Block & 3 & $190 \times 10^{9 \mathrm{~ns}}$ & $144 \times 10^{10 n s}$ & $149 \times 10^{10 n s}$ & $239 \times 10^{10 \mathrm{~ns}}$ & $88 \times 10^{10 \mathrm{~ns}}$ & $76 \times 10^{12 \mathrm{~ns}}$ \\
\hline Error & 12 & $356 \times 10^{9}$ & $49 \times 10^{10}$ & $74 \times 10^{10}$ & $107 \times 10^{10}$ & $184 \times 10^{10}$ & $46 \times 10^{12}$ \\
\hline CV (\%) & & 3.70 & 2.97 & 4.04 & 6.23 & 1.51 & 4.17 \\
\hline
\end{tabular}

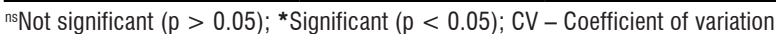


alcohol. As to the technological aspect, the stalks consist of juice, which is formed by water and total soluble solids (sugars and non-sugars), and water-insoluble solids, represented by the fiber (Fernandes, 2003), with an inverse relationship between BRIX and fiber (F) (Franco et al., 2010). The results obtained in the present study show that, in absolute values, the highest values of BRIX and POL were obtained at the dose of $100 \mathrm{~kg} \mathrm{~N} \mathrm{ha}^{-1}$ without causing alteration in F. According to Korndörfer et al. (1997), from the industrial point of view, this can be an interesting effect of $\mathrm{N}$, because the industry increases sugar production and also maintains its energetic balance, since fibers are used for burning in the boilers and the generated vapor is transformed into electrical energy for the supply of the industry.

Arguably, $\mathrm{N}$ favors the absorption of calcium, a fundamental element in the saline composition of the cytoplasm and in the composition of the cell wall, as calcium pectate, which results in greater structuration of cells and favors water absorption; however, high doses can negatively affect the technological quality of the product (Prado \& Pancelli, 2006). Indeed, $\mathrm{N}$ fertilization is usually associated with greater vegetative growth, which invariably leads to plants with higher water contents, but with impairment in sucrose accumulation (Megda et al., 2012). These impairments result from the conversion of sucrose into simple sugars directed to vegetative growth, as a consequence of the association of high $\mathrm{N}$ levels and full irrigation (Bahrani et al., 2009).

The results also show that $\mathrm{N}$ fertigation affected juice apparent purity (PUR) and total recoverable sugar (TRS) of sugarcane (Table 1). However, the follow-up analysis of the degrees of freedom for $\mathrm{N}$ doses did not show statistical significance for both variables, with increase in the values until the application of $100 \mathrm{~kg} \mathrm{~N} \mathrm{ha}^{-1}$ and expressive reduction with the application of $200 \mathrm{~kg} \mathrm{~N} \mathrm{ha}^{-1}$ (Table 2). In some studies with sugarcane under irrigation associated with increasing $\mathrm{N}$ doses, there was a reduction of juice apparent purity (Bahrani et al., 2009). Other researches also pointed out the reduction in TRS of sugarcane under the effect of $\mathrm{N}$ doses higher than $120 \mathrm{~kg} \mathrm{ha}^{-1}$ (Franco et al., 2008; 2010).

PUR reflects the relationship between the contents of sucrose (actual or apparent) and all the other soluble solids (Fernandes, 2003). Considering this aspect and the observation that both variables, BRIX and POL, increased until the application of $100 \mathrm{~kg} \mathrm{~N} \mathrm{ha}^{-1}$ and were significantly reduced from the dose of $150 \mathrm{~kg} \mathrm{~N} \mathrm{ha}^{-1}$ on (Table 2), the same pattern of response can be justified for PUR.

Furthermore, PUR is used in the analysis of raw-material quality, since the industrial unit may refuse loads of stalks with purity below 75\%. Despite the reduction in PUR from $150 \mathrm{~kg}$ $\mathrm{N} \mathrm{ha}^{-1}$ on, the quality of sugarcane juice was maintained, due to the high content of sucrose, since it showed values above 85\% (Fernandes, 2003).

The system proposed for the payment of sugarcane in the state of São Paulo is based on the analysis of quality in TRS (Dalri \& Cruz, 2008), which represents the amount of sugars (in the form of inverted sugars or total reducing sugars) recovered in the sugarcane mill, expressed in $\mathrm{kg} \mathrm{t}^{-1}$ cane, considering losses of $12 \%$ in the sugarcane washing, extraction (loss of pol in the final bagasse), filter cakes or presses and the other losses (Fernandes, 2003).
Considering that there is a consensus in the literature on the effects of adding $\mathrm{N}$ in the production of sugar per area, i.e., the fact that the concentration of sucrose in the stalks can decrease in response to the excess of $\mathrm{N}$ fertilization (Muchow et al., 1996; Franco et al., 2008), doses higher than $100 \mathrm{~kg} \mathrm{~N}^{-1}$ promoted significant reduction in TRS, which may compromise the quality of the produced sugar and, consequently, reduce the profitability of the payment system. However, the total amount of sugar produced per hectare becomes superior due to the higher stalk yield (Korndörfer et al., 1997; Megda et al., 2012), as observed in the present study.

The increasing doses of $\mathrm{N}$ promoted significant effects on the variables TStH and TSgH (Table 3); thus, there was a considerable increase in $\mathrm{TStH}$ and $\mathrm{TSgH}$ proportional to the application of $\mathrm{N}$ doses through subsurface drip fertigation (Figures 3A and 3B, respectively). The doses of 150 and 200 $\mathrm{kg} \mathrm{N} \mathrm{ha}{ }^{-1}$ promoted stalk yields of 106.7 and $122.3 \mathrm{t} \mathrm{ha}^{-1}$, respectively (Figure 3A) and sugar yields of 17.5 and $20.2 \mathrm{t} \mathrm{ha}^{-1}$, respectively (Figure $3 \mathrm{~B}$ ), superior to the $\mathrm{TSgH}$ obtained by Fortes et al. (2013), whose values were close to $16.5 \mathrm{t} \mathrm{ha}^{-1}$, in response to $\mathrm{N}$ fertilization in sugarcane under minimum tillage. Wiedenfeld \& Enciso (2008) obtained TStH of 108 and $115 \mathrm{t}$ $\mathrm{ha}^{-1}$ and second ratoon at the doses of 70 and $140 \mathrm{~kg} \mathrm{~N} \mathrm{ha}^{-1}$ applied through subsurface drip irrigation. These results may indicate that $\mathrm{N}$ demand in the ratoon of irrigated sugarcane can be higher than the currently recommended dose for rainfed management, which ranges from 100 to $120 \mathrm{~kg} \mathrm{~N} \mathrm{ha}^{-1}$ for expected yields above $100 \mathrm{t}^{\text {stalks ha-1 }}{ }^{-1}$ (Raij \& Cantarella, 1997).

Arguably, many authors have demonstrated that, in ratoon cane, the potential of response to $\mathrm{N}$ fertilization is superior, more frequent and requires higher doses of this nutrient, compared with plant cane (Megda et al., 2012). Some studies conducted with sugarcane also reported the increase in stalk yield for the crop under drip fertigation (Dalri \& Cruz, 2008). Adequate management of drip irrigation can increase the efficiency of use of water and nutrients for plants, such as nitrogen, resulting in increment of stalk yield (Ng Kee Kwong et al., 1999).

The currently recommended $\mathrm{N}$ doses probably underestimate the potential of economic response to $\mathrm{N}$ in sugarcane fields with more productive genetic material, cultivated in environments of higher yields and large amounts of crop residues (straw), with high C:N ratio (Megda et al., 2012). In addition, the application of $\mathrm{N}$-fertilizer in ratoon cane is necessary and has great variations, depending on soil management and type (Gava et al., 2001); thus, fertigation

Table 3. Mean squares of the analysis of variance for the yield of stalks (TStH) and sugar (TSgH) of sugarcane, obtained for nitrogen doses (0,50, 100, 150 and $200 \mathrm{~kg}$ $\left.\mathrm{ha}^{-1}\right)$ applied through subsurface drip fertigation

\begin{tabular}{lccc}
\hline \multirow{2}{*}{$\begin{array}{c}\text { Source } \\
\text { of variation }\end{array}$} & \multirow{2}{*}{ DF } & \multicolumn{2}{c}{ Mean squares } \\
\cline { 3 - 4 } Nitrogen doses $(\mathrm{N})$ & 4 & $0.0246 \times 10^{17^{* *}}$ & $0.6998 \times 10^{18^{* *}}$ \\
Block $(\mathrm{B})$ & 3 & $0.0013 \times 10^{17 \mathrm{~ns}}$ & $0.0003 \times 10^{18 \mathrm{~ns}}$ \\
Error (E) & 12 & $0.0003 \times 10^{17}$ & $0.0001 \times 10^{18}$ \\
CV $(\%)$ & & 6.76 & 8.18 \\
\hline
\end{tabular}

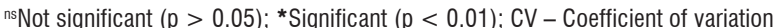


A.

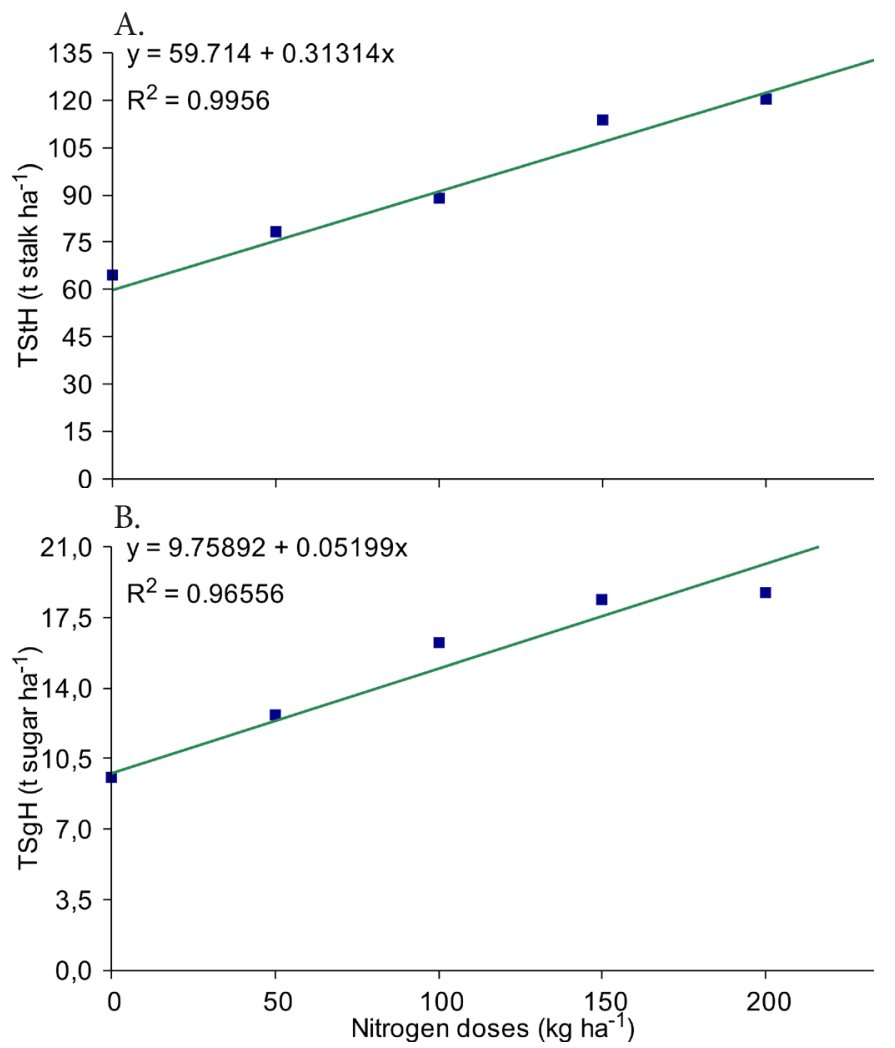

Figure 3. Mean values of stalk yield (TStH) - A, and sugar yield $(\mathrm{TSgH})-\mathrm{B}$, of sugarcane, obtained under nitrogen doses $\left(0,50,100,150\right.$ and $\left.200 \mathrm{~kg} \mathrm{~N} \mathrm{ha}^{-1}\right)$ applied through subsurface drip fertigation

with $\mathrm{N}$ becomes relevant and compensatory for obtaining yield gains.

\section{Conclusions}

1. The technological variables Brix, pol\% juice, purity\% and total recoverable sugar (TRS) of the sugarcane cultivar SP80-3280 were altered by the application of nitrogen doses through subsurface drip fertigation, with significant reductions at the dose of $200 \mathrm{~kg} \mathrm{~N} \mathrm{ha}^{-1}$.

2. Stalk and sugar yields increased linearly with the increment in nitrogen doses applied through subsurface drip fertigation.

\section{ACKnowledgments}

To the Coordination for the Improvement of Higher Education Personnel (CAPES) and the National Council for Scientific and Technological Development (CNPq), for the scholarships and productivity in research fellowship to the last author, respectively, and the São Paulo Agency for Agribusiness Technology (APTA), especially to Dr. Glauber J.C. Gava, for the installations and infrastructure provided for the experiment.

\section{Literature Cited}

Bahrani, M. J.; Shomeili, M.; Zande-Parsa, S. H.; Kamgar-Haghighi, A. Sugarcane responses to irrigation and nitrogen in subtropical Iran. Iran Agricultural Research, v.28, p.17-26, 2009.
CONAB - Companhia Nacional de Abastecimento. Acompanhamento da safra brasileira: cana-de-açúcar, segundo levantamento, agosto/2014. Brasília: CONAB 2014. 20p.

Dalri, A. B.; Cruz, R. L. Produtividade da cana-de-açúcar fertirrigada com N e K via gotejamento subsuperficial. Engenharia Agrícola, v.28, p.516-524, 2008. http://dx.doi.org/10.1590/S010069162008000300012

Dalri, A. B.; Cruz, R. L.; Garcia, C. J. B.; Duenhas, L. H. Irrigação por gotejamento subsuperfical na produção e qualidade de cana-deaçúcar. Irriga, v.13, p.1-11, 2008.

Dantas Neto, J.; Figueredo, J. L. C.; Farias, C. H. A.; Azevedo, H. M. de; Azevedo, C. A. V. de. Resposta da cana-de-açúcar, primeira soca, a níveis de irrigação e adubação de cobertura. Revista Brasileira de Engenharia Agrícola e Ambiental, v.10, p.283-288, 2006. http:// dx.doi.org/10.1590/S1415-43662006000200006

EMBRAPA - Empresa Brasileira de Pesquisa Agropecuária. Centro Nacional e Pesquisa em Solos. Sistema brasileiro de classificação de solos. Brasilia: Embrapa SPI; Rio de Janeiro: Embrapa-Solos, 2006. 306 p.

Fernandes, A. C. Cálculos na agroindústria canavieira. 2ed. Piracicaba: STAB - Sociedade dos Técnicos Açucareiros e Alcooleiros do Brasil, 2003. 240p.

Fortes, C.; Trivelin, P. C. O.; Vitti, A. C.; Otto, R.; Franco, H. C. J.; Faroni, C. E. Stalk and sucrose yield in response to nitrogen fertilization of sugarcane under reduced tillage. Pesquisa Agropecuária Brasileira, v.48, p.88-96, 2013. http://dx.doi. org/10.1590/S0100-204X2013000100012

Franco, H. C. J.; Trivelin, P. C. O.; Faroni, C. E. F.; Vitti, A. C.; Otto, R. Aproveitamento pela cana-de-açúcar da adubação nitrogenada de plantio. Revista Brasileira de Ciência do Solo, v.32, p.2763-2770, 2008. http://dx.doi.org/10.1590/S0100-06832008000700021

Franco, H. C. J.; Trivelin, P. C. O.; Faroni, C. E. F.; Vitti, A. C.; Otto, R. Stalk yield and technological attributes of planted cane as related to nitrogen fertilization. Scientia Agricola, v.67, p.579-590, 2010. http://dx.doi.org/10.1590/S0103-90162010000500012

Gava, G. J. C.; Silva, M. A.; Silva, R. C.; Jeronimo, E. M.; Cruz, J. C. S.; Kölln, O.T. Produtividade de três cultivares de cana-de-açúcar sob manejos de sequeiro e irrigado por gotejamento. Revista Brasileira de Engenharia Agrícola e Ambiental, v.15, p.250-255, 2011. http:// dx.doi.org/10.1590/S1415-43662011000300005

Gava, G. J. C.; Trivelin, P. C. O.; Oliveira, M. W.; Penatti, C. P. Crescimento e acúmulo de nitrogênio em cana-de-açúcar cultivada em solo coberto com palhada. Pesquisa Agropecuária Brasileira, v.36, p.13471354, 2001. http://dx.doi.org/10.1590/S0100-204X2001001100004

Howell, T. A.; Evett S. R. The Penman-Monteith method. Washington, DC: USDA-Agricultural Research Service, Conservation \& Production Research Laboratory, 2004. 14p.

Korndörfer, G. H.; Valle, M. R.; Martins, M.; Trivelin, P. C. O. Aproveitamento do nitrogênio da uréia pela cana-planta. Revista Brasileira de Ciência do Solo, v.21, p.23-26, 1997.

Megda, M. X. V.; Trivelin, P. C. O.; Franco, H. C. J.; Otto, R.; Vitti, A. C. Eficiência agronômica de adubos nitrogenados em soqueira de cana-de-açúcar colhida sem queima. Pesquisa Agropecuária Brasileira, v.47, p.1681-1690, 2012. http://dx.doi.org/10.1590/ S0100-204X2012001200002

Mozambani, A. E.; Pinto, A. S.; Segato, S. V.; Mattiuz, C. F. M. História e morfologia da cana-de-açúcar. In: Segato, S. V.; Pinto, A. S.; Jendiroba, E.; Nóbrega, J. C. M. (org.). Atualização em produção de cana-de-açúcar. Piracicaba: ESALQ/USP, 2006. p.11-18. 
Muchow, R.C.; Robertson, M.J.; Wood, A.W.; Keating, B.A. Effect of nitrogen on the time-course of sucrose accumulation in sugarcane. Field Crops Research, v.47, p.143-153, 1996. http:// dx.doi.org/10.1016/0378-4290(96)00022-6

Ng Kee Kwong, K. F.; Paul, J. P.; Deville, J. Drip-fertigation - A means for reducing fertilizer nitrogen to sugarcane. Experimental Agriculture, v.35, p.31-37, 1999. http://dx.doi.org/10.1017/ S0014479799001040

Prado, R. M.; Pancelli, M. A. Nutrição em soqueira e a qualidade tecnológica da cana-de-açúcar. STAB. Açúcar, Álcool e Subprodutos, v.25, p.60-63, 2006.

Quintana, K. A.; Zanini, J. R.; Silva, E. R. Irrigação e fertirrigação por gotejamento em cana-de-açúcar na presença e ausência de boro. Científica, v.40, p.103-116, 2012.

Raij, B. van; Cantarella, H. Outras culturas industriais. In: Raij, B. van; Cantarella, H.; Quaggio, A. J.; Furlani, A. M. C. (ed.). Recomendações de adubação e calagem para o estado de São Paulo. 2.ed. Campinas: IAC, 1997. p.8-13. Boletim Técnico, n. 100
Roberts, T. L. Improving nutrients use efficiency. Turkish Journal of Agriculture and Forestry, v.32, p.177-182, 2008.

Silva, M. A.; Arantes, M. T.; Rhein, A. F. L.; Gava, G. J. C.; Kolln, O. T. Potencial produtivo da cana-de-açúcar sob irrigação por gotejamento em função de variedades e ciclos. Revista Brasileira de Engenharia Agrícola e Ambiental, v.18, p.241-249, 2014. http:// dx.doi.org/10.1590/S1415-43662014000300001

Silva, M. A.; Silva, J. A. G.; Enciso, J.; Sharma, V.; Jifon, J. Yield components as indicators of drought tolerance of sugarcane. Scientia Agricola, v.65, p.620-627, 2008. http://dx.doi.org/10.1590/ S0103-90162008000600008

Vale, D. W.; Prado, R. M.; Cantarella, H.; Fonseca, I. M.; Avalhães, C. C.; Correia, M. A. R.; Barbosa, M. P. Ammonium and nitrate in soil and ratoon sugarcane grown in function of nitrogen on Oxisol. Journal of Plant Nutrition, v.36, p.201-213, 2013. http:// dx.doi.org/10.1080/01904167.2012.739241

Wiedenfeld, R.; Enciso, J. Sugarcane responses to irrigation and nitrogen in semiarid south Texas. Agronomy Journal, v.100, p.665671, 2008. http://dx.doi.org/10.2134/agronj2007.0286 